\title{
A Self-Survey of the University of Alabama Libraries
}

A Self-survey sometimes takes the A form of investigating one or more processes of a department or it may consist of a study and analysis of the library's complete operations, including an analysis of the book collection, administration, finance, departmentalization, work procedures, and other matters and activities.

In September 1940, when the University of Alabama began a self-survey of its libraries, a special fund was established for the expense of the project and for the purchase of recommended books and periodicals. The survey was conducted by the director of libraries and two specially appointed assistants, with the cooperation of the faculty.

There were two major aims: the first was to describe in detail the titles, types of material, and subjects represented in the university's book collections; the second was to plan a book-buying program for the future, including subject areas of desired emphasis, types of material to be acquired, and specific titles recommended for purchase.

Closely related to the general aims were several other projects. A survey of book markets was to be made to determine the best sources of purchase. A consultation service was to be made available to the faculty to assist in selecting library materials. A new book-ordering procedure and a more adequate system of library records were to be inaugurated.

In order to proceed effectively it was considered necessary to obtain a clear statement of the university's aims and future program, together with those of the various schools, colleges, and subject departments. These statements would show where emphasis should be placed in the buying program. They would indicate the addition, omission, or strengthening of any major fields of study within schools or departments and would also show at what level any change was likely to occur: undergraduate, graduate, or research. Contact was made with each department head and dean to obtain, if possible, such a statement. Although some of the deans indicated new subject fields that might possibly be added to certain schools and colleges, department heads were more easily able to suggest new courses which would probably be added to their curricula.

The questionnaire sent to deans, department heads, and other policy-determining officials was as follows:

I. What are the aims or objectives which your school or department is trying to achieve in the categories mentioned below:

(a) In undergraduate teaching?

(b) In graduate instruction?

(c) In individual research?

(d) In extension work or other undertakings?

2. What is the method by which new book orders and periodical subscriptions are determined in your school or department? Are you satisfied with this type of selection? If not, please state criticisms or suggestions.

Broad principles of future university policy were sought from the president and other administrative officials. Since these 
principles would necessarily be different and more general than those of the deans and department heads, they could not be formulated as easily. The best information that could be obtained was that the university was embarking on an expanded program of instruction which would probably, in the future, include the doctoral degree. The first thing to be accomplished, however, was to improve facilities for undergraduate instruction and work for the master's degree.

The most important part of the survey was to evaluate the resources of the university libraries and to build up the collection. When the survey was inaugurated, notices were sent to all faculty members inviting them to discuss their needs in the various subject fields with the director of libraries and the survey assistants. Many individual faculty members, department heads, and deans came to the library in response to this invitation. Some departments and schools held faculty meetings to which they asked members of the survey staff to come and discuss their library problems in detail.

A questionnaire was sent to the faculty asking the following:

I. What is your teaching load per week (credit hours)?

2. What research projects are you carrying on?

3. Can you supply us with a list of books cited in all the courses you teach? Do you use a syllabus for each course?

4. What professional literature do you consult regularly?

5. What professional materials do you need which the library does not have?

6. What can the library do to make itself more useful to you individually?

7. What can the library do to make itself more useful to you as a teacher?

8. Do you know of any bibliographies which the library should check for possible purchases?
9. Are you willing to check book catalogs, etc., which the library will supply?

10. Important library holdings (please indicate): Undergraduate-Graduate-Research

Some faculty members recommended bibliographies to be checked. For example, one English professor suggested that the library should have every book reviewed in the periodical, American Literature, not including books that were listed without being reviewed. The first eleven volumes contained 608 titles, of which the library had 332. The remaining 276 titles have been purchased or are on order and those in subsequent volumes have been obtained.

Another group of bibliographies suggested by the faculty was that on various fields of engineering published by the Engineering Council for Professional Development. The five bibliographies in this series were checked and, of 1335 titles listed, the university owned 575. Many of these titles have been purchased since, so that now the university libraries have more than 50 per cent as compared with 43 per cent when the lists were checked.

From many other bibliographies suggested by the faculty, purchases have been made for titles that were not in the libraries.

In one subject field a more thorough check was made at the request of the department head. The pertinent parts of the shelflist of a large university library, which has one of the largest and best collections on that subject, were microfilmed and slips were typed from the film. It was realized that the University of Alabama would probably never need to duplicate this collection, but the film was obtained so that selections could be made by the department for library acquisition.

In addition to suggesting bibliographies, some of the faculty made intensive studies of their subject fields in a manner similar to those studies made for the Pennsylvania 
survey. ${ }^{1}$ From these studies they submitted requests.

In addition to the evaluation of the libraries' resources made by the faculty, a few library staff members checked the libraries' holdings in fields of their subject knowledge. Their findings were coordinated with those of the faculty members in the same subject fields.

\section{Checked Bibliographies}

To supplement the faculty study, the survey staff checked approximately seventy-five standard and authoritative bibliographies. Some of these were general, such as Shaw's List of Books for College Libraries and Supplement and Mohrhardt's List of Books for Junior College Libraries. Some were subject bibliographies, such as Crane's Guide to the Literature of Chemistry, Scholes' List of Books about Music in the English Language, Altsheler's National History Index-Guide, Bentley's Bibliography of Works on Accounting by American Authors, Burchfield's Student's Guide to Materials in Political Science, etc. Still others were bibliographies in standard textbooks. Reference lists issued by the North Central Association of Colleges and Secondary Schools and the Southern Association of Colleges and Secondary Schools were checked. Lyle's Classified List of Periodicals for the College Library was used, in addition to the periodical lists compiled by Shaw, Mohrhardt, the North Central Association, and the Southern Association.

It was thought that eventually all of the books and periodicals listed in Shaw, Lyle, the North Central Association, the Southern Association, and perhaps Mohrhardt, should probably be in the university li-

\footnotetext{
${ }^{1}$ Bibliographical Planning Committee of Philadelphia. A Faculty Survey of the University of Pennsylvania Libraries. Philadelphia, University of Pennsylvania Press, 1940.
}

braries. On the other hand, the libraries could not hope to buy, and would probably have no use for, all of the titles listed in Crane, Scholes, and certain other inclusive bibliographies.

From all of the lists checked a composite table of broad subjects, such as ancient languages, art, business and economics, chemistry, etc., was made. If a more specialized subject bibliography, e.g., theatre, was checked, it was put into the most closely related larger subject, e.g., speech. The subjects were listed, together with the number of titles in the publications and the per cent of titles in the university libraries.

\section{Checking Interlibrary Loans}

Another method of determining possible needs was the checking of interlibrary loan correspondence for several years. Records were made of the requests and a majority of the books requested frequently was purchased. Periodical requests were examined more critically. If a definite need was indicated, a current subscription was placed and an attempt made to complete the set.

Certain outstanding titles were purchased when found, even before the survey was completed. A complete bound file of the Times (London) and its index from I 839 to date were obtained. Bound volumes of the New York Times were completed back to $I 920$ and earlier volumès will probably be obtained on microfilm.

The final result of the survey of library resources was the compilation of a file of needed materials that would probably cost several hundred thousand dollars to purchase. Some of the items were to be purchased from the regular book budget.

As each subject was completed a report was compiled. This report included:

1. An evaluation of book holdings by authoritative bibliographies 
2. An evaluation of periodical holdings by authoritative bibliographies

3. An evaluation of all titles requested by faculty members

4. Tables showing needs with their approximate cost

5. An attempt to compare present holdings with data in Downs's Resources of Southern Libraries

6. Conclusions and recommendations.

From time to time mimeographed memoranda were sent to the faculty to keep them informed of the progress of the survey and to request their continued participation.

From the questionnaire sent to the faculty the survey staff was able to obtain a general idea of faculty needs, many of which resulted in new services and procedures.

\section{New Order Procedure}

A new order procedure was definitely needed. A new order card was designed in duplicate so that the requestor could keep his own record of all titles ordered. A system was developed whereby book and periodical orders, previously placed through the purchasing agent of the university, could be placed directly from the library, thus facilitating receipt of the orders. A quadruplicate manifold process was adopted consisting of the official order, dealer's record, Library of Congress card order, and faculty notice. The whole new order procedure was-more economical and efficient.
The physical arrangement of the library was changed so that service could be increased. Some staff members were changed to different positions and the number of staff members was almost doubled. Departmental organization was changed to increase efficiency.

The initial work of the survey was completed in a year and a half. Purchases of recommended materials have continued over the past five years but have been hindered by the unavailability of foreign materials. Special funds are now available for foreign and domestic purchases.

\section{Accomplishments}

The fundamental accomplishments of the survey have been a compilation of needed books and periodicals from which to make purchases and a reorganization of library procedures and personnel so as to give the best possible service to the library's patrons. In addition, the staff and budget have been increased by the university administration. In 1939-40, total library expenditures were $\$ 69,987$; in 1940-41, \$110,587. During the early war years the budget had to be decreased. During the past two years the budget has been increased again so that for $1946-47$ it is $\$ 135,000$. The value of the library program at the University of Alabama is recognized by the administration and is generously supported. 